\title{
Web platform for casting process selection
}

\author{
Juliana Ilha Zimmermann ${ }^{a}$, Danielle Bonda, Régis Kovacs Scalice \\ Universidade do Estado de Santa Catarina \\ Universidade Federal de Santa Catarina \\ e-mails: juilhaz@hotmail.com; daniellebond80@gmail.com; regis.scalice@ufsc.br; rkscalice@gmail.com
}

\begin{abstract}
The choice of the right process for casting components is a complex activity that directly impacts on the product's design and manufacturing. A single failure in the casting process selection can increase design and production time and, in critical cases, result in a collapse of the manufacturing and assembly of components. In this context, our goal is to adapt a previously developed method for casting process selection into a Web platform to aid the casting process selection. The adopted selection method uses Quality Function Deployment (QFD) and Design for Manufacturing (DFM) principles to provide a structure to support casting selection decision based on part features and process demands. The proposed software was developed for the Web using HTML and JavaScript, providing better usability than the previously proposed selection method format using spreadsheets. For validation, ferrous and nonferrous cast parts were analyzed using the proposed Web platform. The results showed a good relation to other methods, also providing a quantitative classification (prioritization) of the results. In addition, this software supports the design of the manufacturing process by means of a checklist to adapt the part to the metal casting process presented to the designer.
\end{abstract}

Keywords: casting process, process selection, web platform, quality function deployment, design for manufacturing.

\section{Introduction}

Brazil is one of the ten largest producers of castings in the world, producing about two and a half million tons of molten material per year. Furthermore, in 2014, the country produced an average of 10 tons a day. This industrial segment employs about 62000 people in almost 1300 companies. Most of those enterprises are small and medium-sized, mainly started with investments from national capital sources (ASSOCIAÇÃO..., 2012).

The choice of the casting process directly influences the dimensional accuracy, finishing and mechanical properties of the component to be manufactured (FERREIRA, 1999). The right process choice usually ensures reduced costs and production time, increasing reliability due to the lower probability of failure in production. Despite the existence of many methods for manufacturing molten parts, the designers tend to use familiar materials and processes, which is still a prevalent tradition. This action results in the detriment of processes and combinations of materials that could be more economical (BOOTHROYD; DEWHURST; KNIGHT, 2011).

According to Swift and Booker (2003), some designers are experienced and understand the limitations of each process they deal with; however, a lot of them do not understand the risks of a poor choice. An incorrect manufacturing process choice results in a substantial increase in design and production time and increases the chances of failure during manufacture and assembly.

Ashby (2005) emphasizes the importance of specifying the functions related to the needs of the consumer or product operation. In addition, according to Lovatt and Shercliff (1998a, b), the selection of the manufacturing process is influenced by the material and the shape of the component. Such relation between function, form and material is essential to understand the ways of selecting manufacturing processes (CHANG; CHEN, 2014; COCHRAN et al., 2016; AKARTE; RAVI, 2007; SUN et al., 2014).

Several methods for process selection can be found in the literature, including: expert systems, process information maps, rational methods, set of rules and multicriteria methods (LOVATT; SHERCLIFF, 1998b; ER; DIAS, 2000; DARWISH; TAMIMI; AL-HABDAN, 1997; KARTHIK et al., 2003). A particularly unanimous procedure among the cited selectors is a comparison between the part's features and the parameters of each process. Darwish, Tamimi and Al-Habdan (1997) and Setti (2010) consider the characteristics with different weights, resulting on a different importance for each. Only Swift and Booker (2003) considers the component's requirements during project development, at the end of the selection process, in order to compare it to the obtained requirements. 
Finally, Karthik et al. (2003) and AFS (AMERICAN..., 2015) applied their respective selectors on a Web platform. The Web format is independent on the operational system and does not need a special configuration or download to work. On the Web platform, users may access from anywhere, at any time, needing only a Web browser (WANG et al., 2011; PULLAN, 2014).

In this context, our goal is to adapt a previously developed method for casting process selection into a Web platform to aid the casting process selection.

\section{Methodology}

The Web platform was developed using html and JavaScript, and was based on the Santos et al. (2017) selector. The methodology embedded on this Web selector combines QFD and DFM concepts and aims to choose the most appropriate casting process during the product design phases (ELGH, 2014; KNIGHT; COWELL; PREDDY, 1995; NICHOLDS; MO; BRIDGER, 2014). The interaction between those tools is described in the flowchart in Figure 1.

Geometrical characteristics of the components, as well as project requirements, are the starting point to distinguish the material nature and to provide the component's functions and characteristic values (VOSNIAKOS et al., 2009; JONES; YUAN, 2003; KUMAR; MADAN; GUPTA, 2013). Based on the input data, the selector is able to generate a ranking of casting processes, indicating the most appropriate. To complete the selection, a checklist is provided in order to correct the component's parameters, or to adapt the project to fit the characteristics of the process in order to make it more efficient.

Santos et al. (2017) propose to differentiate between ferrous and non-ferrous metals, since some casting processes cannot be applied to both cases. The characteristic

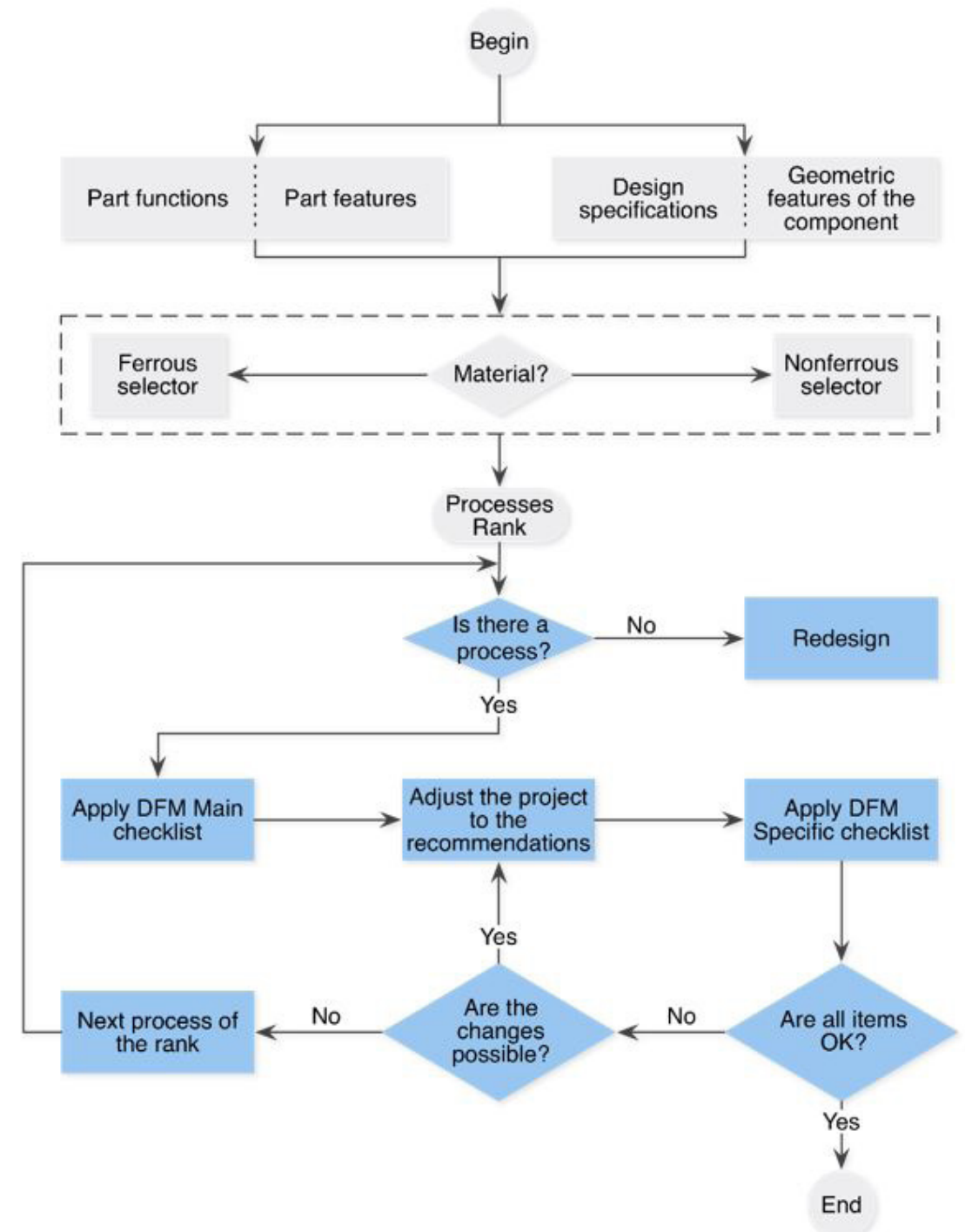

Figure 1. Selector operation flowchart integrating the DFM (SANTOS et al., 2017). 
values which should be provided by the designer are: mass, minimum section thickness, draft angle, surface finish, dimensional tolerances, minimum lot and lead time. Due to the fact that the part's dimension is directly linked to the value of the dimensional tolerance, it is necessary to inform the greater dimensional value for the desired tolerance.

The starting point to use this selector is during the product's embodiment design, which has already set much of the product's architecture and some parts were selected as candidates for the casting process. In addition, its function and some desired design parameters are already known (geometry, finishing, materials and others), which provides more suitable information for the selector. The conceptual model used, shown in Figure 2, consists of two parts: (a) a correlation matrix and (b) a selection matrix.
The correlation matrix gathers the associations between component functions and applications, named "description" in the proposed selector, with the casting process characteristics, in order to obtain their importance (mass, minimum section thickness, draft angle, surface finish, dimensional tolerances, minimum lot and lead time). In this matrix, the correlation must comply with the scale ranging from 0 to 5 , where 0 means no correlation and 5 means a very strong correlation. In the Web platform, the matrix was conceived as an interactive Table, shown in Figure 3, where the user can add and remove lines according to the number of functions and product applications, while the value of the characteristic's importance increases or decreases automatically in the last row of the table.

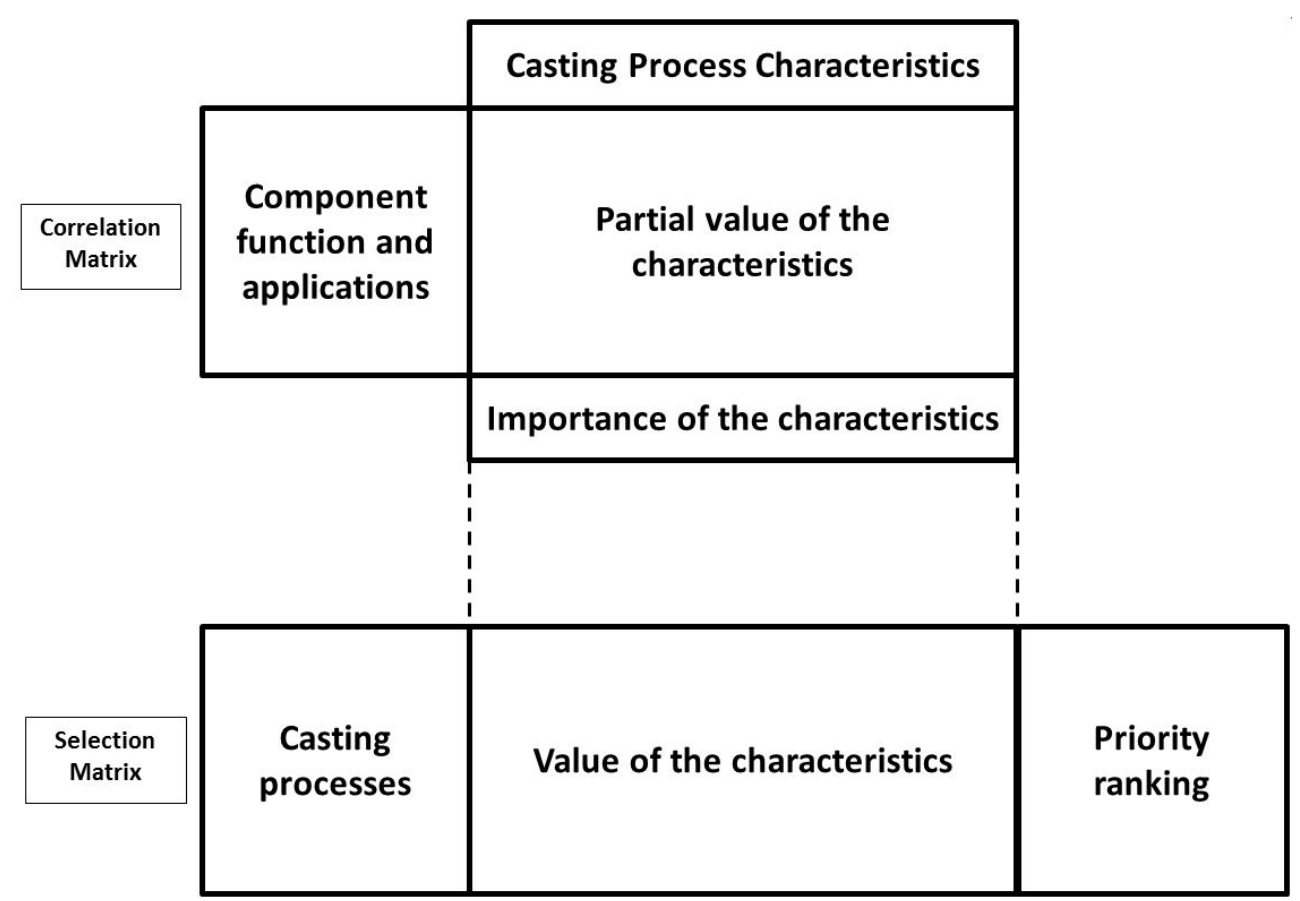

Figure 2. Selector operation flowchart integrating the DFM (SANTOS et al. 2017).

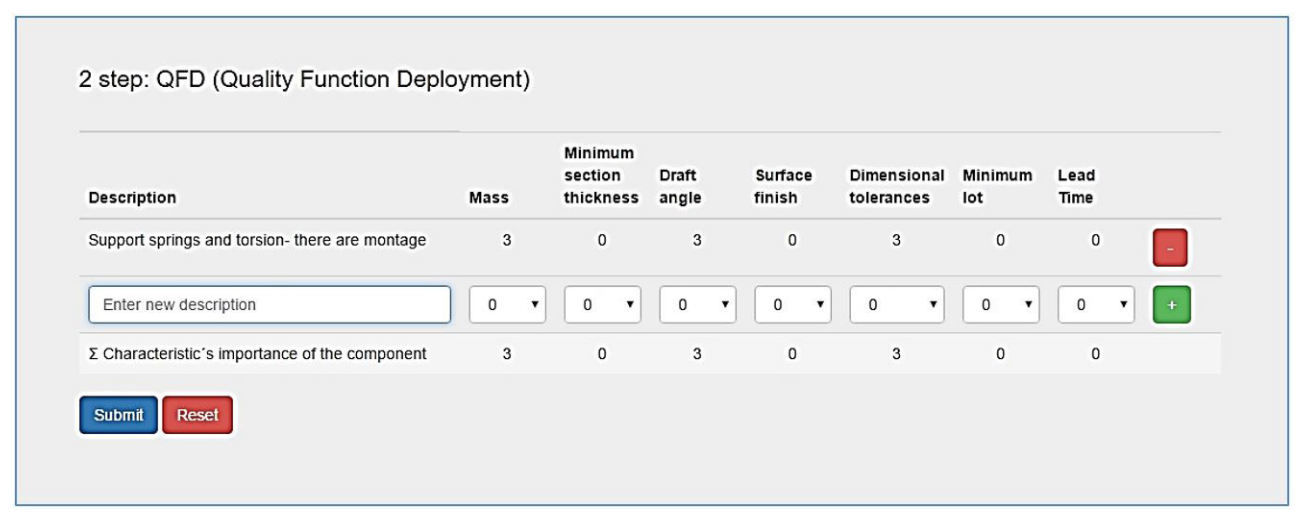

Figure 3. Correlation matrix of the Web platform, based on QFD, in order to obtain the importance of the characteristic values. 
In the selection matrix, to obtain the prioritization, the values of characteristics are compared to the casting processes capabilities. For each process characteristic, Santos et al. (2017) established four levels for the "value of the characteristic", namely: 1) extreme minimum, 2) minimum of 3) maximum and 4) extreme maximum. These values are matched to a database which is already built into the proposed Web platform. To obtain the prioritization rank, the design goals are compared to the values of the characteristics of each casting process. From this comparison, indicators of capability are determined as 0,1 , or 2 , where: 2 means design goal is between minimum and maximum value (within the usual limits); 1 means design goal is between the minimum and extreme minimum, or between maximum and extreme maximum (within the extreme limits); and 0 means design goal is above maximum extreme or below minimum extreme (out of process limits).

The ratio of each characteristic is then obtained by multiplying the value of the corresponding process capability $(0,1$ or 2$)$ by the importance of the characteristic obtained from the correlation matrix. Therefore, the grade for each casting process is the result obtained from the sum of the resulting ratios of the characteristics for each casting process (lines). The results are standardized in the range from 0 to 10 (obtained by dividing them by the maximum value multiplied by 10), hence facilitating the interpretation of the final result. If any process obtains an index 0 in any feature, its final score will be zero. In other words, the process is unable to produce the desired component characteristics.

In order to consider the process characteristics from the embodiment design, and based on the DFM principles, a checklist is also provided as a guide to help designers review their project goals. The checklist is a list of functions to verify and document the selection routine, to keep the process organized and simple (SANTOS et al., 2017). This tool should be used for the highest ranking process and all the fields in the list must be checked. If the features do not comply, changes relating to costs, physical and dimensional limits shall be adjusted until all items are checked. Using the checklist, the designer will be able to adapt the components that will be merged with the requirements of the ranked process, ensuring a higher efficiency in the fabrication process. The checklist (Appendix 1) is provided for download in the Web platform in PDF format.

To validate the Web platform, the obtained results using two components from the industry were evaluated and the results were compared to the ones employed by the industry and the AFS (AMERICAN..., 2015) Web platform.

\section{Evaluation of the Web platform proposal using industrial components}

a) For the process selector validation, real parts applied in the local metalworking industry were used, described in Table 1, being one ferrous and another non-ferrous. They are:

b) Planetary gear housing: component used in the automotive industry, where the planetary gears are engaged;

c) Gate valve: component used in civil construction to interrupt the water flow in an installation.

The item (b) from Table 1 will be used as a model to illustrate, step by step, how the Web platform works. First, the data from Table $1 \mathrm{~b}$ is input by the user in order to fill in the initial web page data.

Table 1. Analyzed components from the metal mechanic industry.

\begin{tabular}{|c|c|c|}
\hline \multirow[b]{2}{*}{ Part } & $\begin{array}{c}\text { (a) } \\
\text { Planetary gear housing }\end{array}$ & $\begin{array}{l}\text { (b) } \\
\text { Gate valve }\end{array}$ \\
\hline & & \\
\hline Material & Nodular cast iron & Brass alloy \\
\hline Mass (kg) & 17.38 & 0.191 \\
\hline Minimum section thickness (mm) & 14 & 2.5 \\
\hline Draft angle $\left(^{\circ}\right)$ & 0.5 & 5 \\
\hline Surface finish $(\mathrm{Ra})$ & 40 & 40 \\
\hline Dimension $(\mathrm{mm})$ & 225 & 28.4 \\
\hline Dimensional tolerance $(\mathrm{mm})$ & \pm 1.4 & \pm 0.3 \\
\hline Minimum lot (components per year) & 300 & 20000 \\
\hline Lead Time (days) & Not specified & Not specified \\
\hline
\end{tabular}


The gate valve is used in civil construction to stop water flow in case of leaking or eventual maintenance. The water pressure, combined with the open and close movement, can wear its internal components out. Based on that information, functions and features of the gate valve were chosen to fill in the correlation matrix (Figure 4): (i) domestic use, (ii) perfect fit to other connections, (iii) has a large-scale production and (iv) does not require painting.

When all inputs and importance are filled in the platform, the Web selector is able to calculate each process' grade, considering characteristics and comparing to minimum and maximum values.
Table 2 illustrates how the proposed algorithm calculates scores for each process, using the gate valve as a component and investment casting as a process example. The values in Table 2, columns c, d, e and f, are embedded on the platform and represent maximum and minimum values.

1. The selector can automatically generate a table with the results, ranking the processes according to the calculated and standardized grades, as Figure 5 illustrates. The results of the Web platform for the gate valve are:

2. Investment casting (10.00)

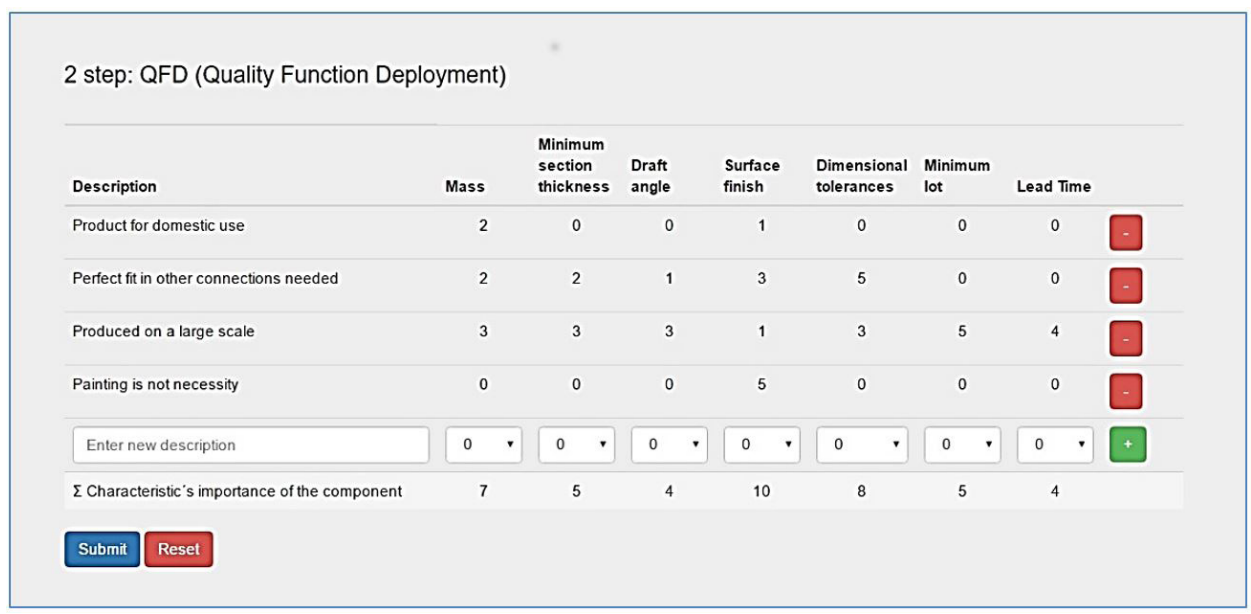

Figure 4. Matrix Correlation filled with importance values of each feature of the gate valve.

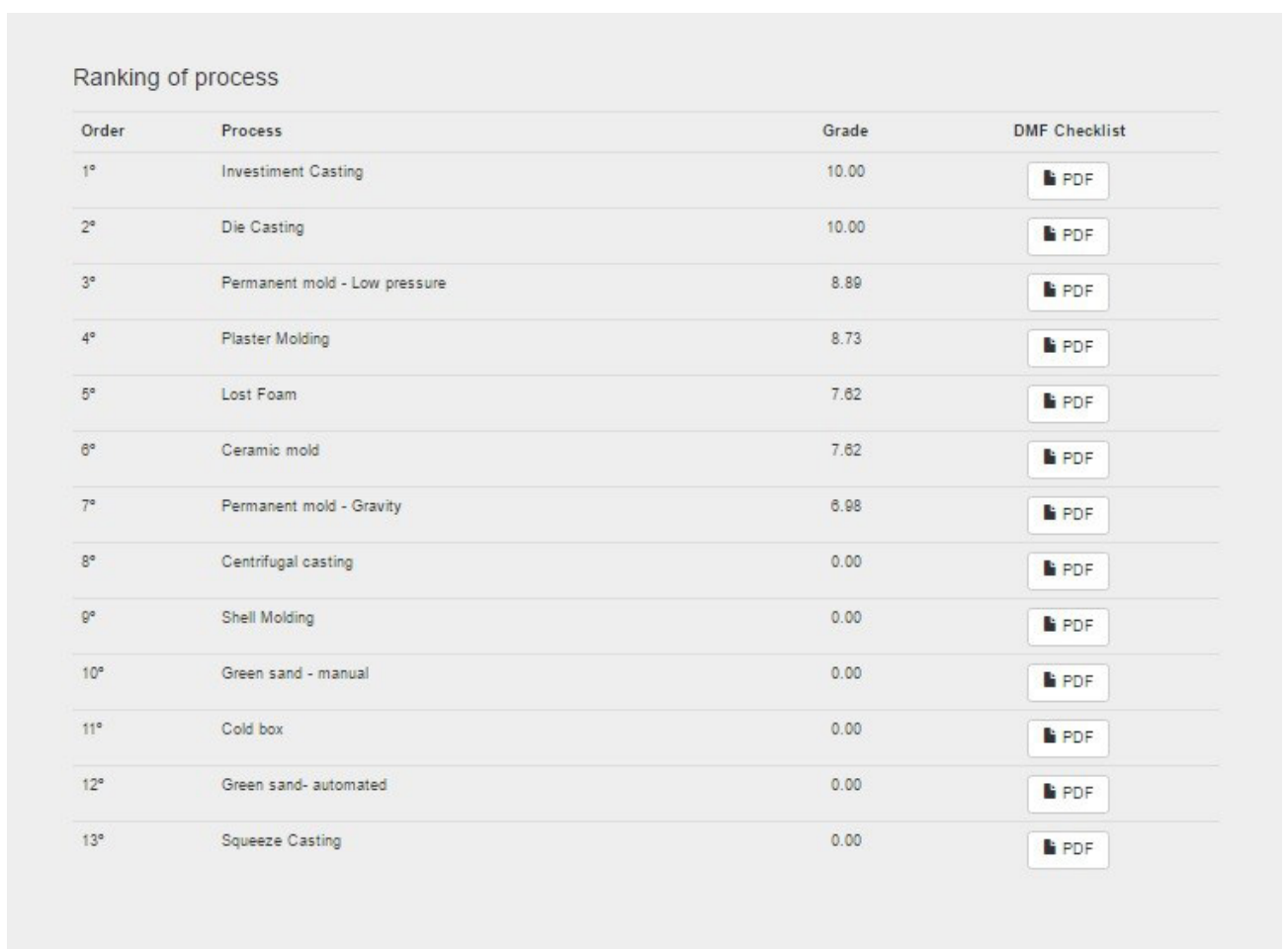

Figure 5. Final ranking of the casting process for the gate valve. 
3. Die casting (10.00)

4. Permanent mold - Low pressure (8.89)

5. Plaster molding (8.73)

6. Lost foam (7.62)

7. Ceramic Mold (7.62)

8. Permanent mold - Gravity (6.98)

For the planetary gear housing, the results are:

1. Investment casting (10.00)

2. Cold box (9.90)

\section{Ceramic Mold (9.49)}

All other processes were considered unable to fabricate the part with the desired characteristics $(0.00)$.

It is worth noticing the small difference between the obtained scores that fulfill the requirements for different casting processes. It demonstrates that the expertise of the designer is still necessary to evaluate process costs and availability for the company. Furthermore, every process has a final check list, based on DFM, included in the web selector, which must have all fields checked by the designer to complete the selection process. If any field is incorrect, the project should be reviewed until all the fields have been checked. As a result, it allows the designer to adapt the project, considering the process selected during development.

Finally, Table 3 compares the results obtained from the proposed platform to the Web selector provided by the American Foundry Society and to processes currently used by the industry. For the ferrous parts, the results are highly similar, however it is not possible to draw the same conclusion for the nonferrous parts, for which the platform results suggest the processes used by the industry, but not with good marks. Difference between results is caused by the selection of the maximum and

Table 2. Summary of the characteristic values and their importance for Investment Casting the gate valve part.

\begin{tabular}{|c|c|c|c|c|c|c|c|c|}
\hline A & $\mathrm{B}$ & $\mathrm{C}$ & $\mathrm{D}$ & $\mathrm{E}$ & $\mathrm{F}$ & $\mathrm{G}$ & $\mathrm{H}$ & $\mathrm{I}$ \\
\hline Part Features & Value & $\begin{array}{l}\text { Extreme } \\
\text { minimum }\end{array}$ & $\begin{array}{l}\text { Ordinary } \\
\text { minimum }\end{array}$ & $\begin{array}{l}\text { Ordinary } \\
\text { maximum }\end{array}$ & $\begin{array}{l}\text { Extreme } \\
\text { maximum }\end{array}$ & $\begin{array}{c}\text { Associated } \\
\text { indicator }\end{array}$ & Importance & $\begin{array}{c}\text { Priority } \\
\text { value of the } \\
\text { characteristic } \\
\text { (column } \mathrm{G} \text { x } \\
\text { column } \mathrm{H}\end{array}$ \\
\hline Mass (kg) & 0.191 & 0.0045 & 0.05 & 6.8 & 113 & 2 & 7 & 14 \\
\hline Minimum section thickness $(\mathrm{mm})$ & 2.5 & 0.23 & 1.04 & $\mathrm{NE}$ & $\mathrm{NE}$ & 2 & 5 & 10 \\
\hline Draft angle $\left({ }^{\circ}\right)$ & 5 & 0 & 1 & $\mathrm{NE}$ & NE & 2 & 4 & 8 \\
\hline Surface finish $(\mathrm{Ra})$ & 40 & 0.73 & 1.14 & 2.86 & $\mathrm{NE}$ & 1 & 10 & 10 \\
\hline Dimensional tolerances (mm) & \pm 03 & 0.16 & 0.28 & $\mathrm{NE}$ & $\mathrm{NE}$ & 2 & 8 & 16 \\
\hline Min. lot (components per year) & 20000 & 1 & 10 & 1760 & NE & 1 & 5 & 5 \\
\hline \multirow[t]{2}{*}{ Lead Time (days) } & NS & 60 & 120 & $\mathrm{NE}$ & $\mathrm{NE}$ & $\mathrm{NI}$ & 4 & NI \\
\hline & \multicolumn{7}{|c|}{ Priority value for the process (not normalized) $\rightarrow$} & 63 \\
\hline
\end{tabular}

NI - Not Informed; NE - Non-existent.

Table 3. Comparison between the proposed selector (1), American Foundry Society platform (2), and the processes used in industry (3).

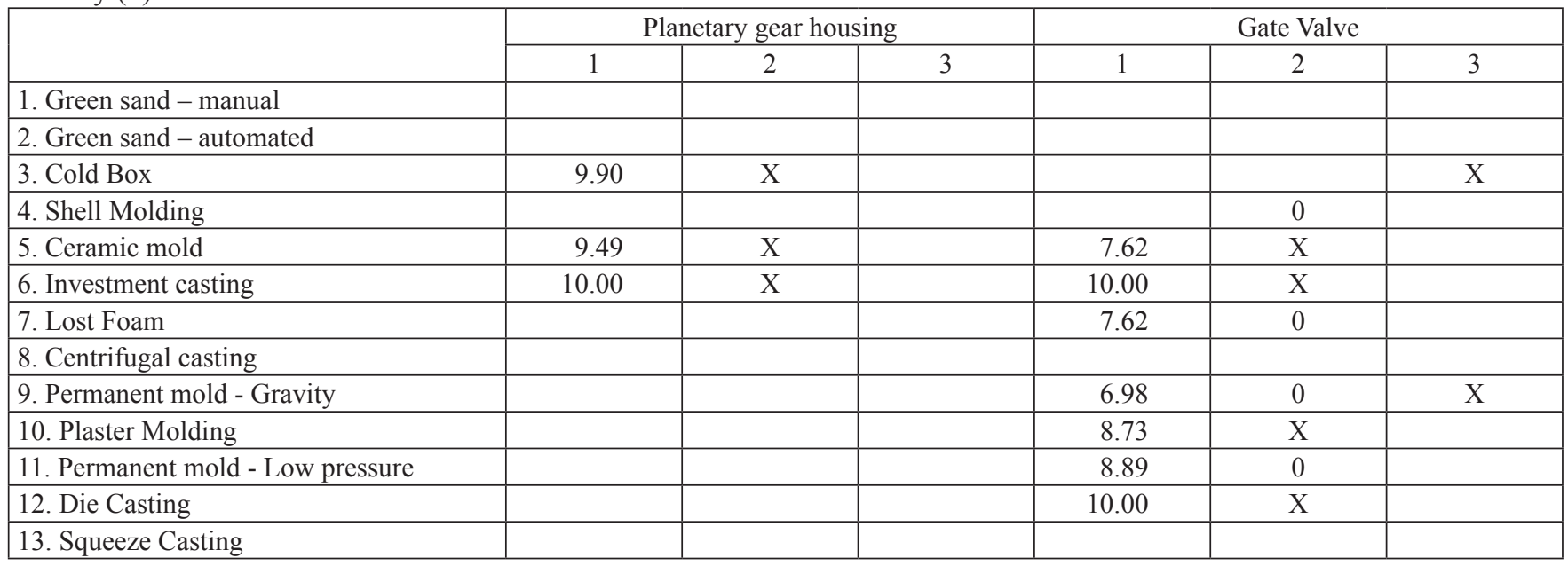


minimum values for each procedure, which was made by comparing the values suggested in different bibliographies cited in Santos et al. (2017), thus producing a wide separation between maximum and minimum extremes. This particularity makes the web selector process much acceptable when the characteristics of the components are compared to the platform database.

A characteristic of the American Foundry Society platform AFS (AMERICAN..., 2015) is that, instead of grading the processes, it just indicates which one agrees with the parameters set. The appropriate procedures for each component tested on that platform are represented in Table 3 by the letter ' $X$ '. Furthermore, the platform alerts users about processes operating in danger conditions, i.e., process which work near the reference limits. Those processes are represented in Table 3, in red. When both selectors are compared, it is possible to relate the processes that received the lowest scores from the proposed web platform to the processes that received the letter ' $\mathrm{O}$ ' from the American Foundry society platform AFS (AMERICAN..., 2015).

\section{Conclusion}

In this paper, a Web platform to aid the selection of casting processes is presented, which uses a previously developed method for such selection. It employs Quality Function Deployment (QFD) and Design for Manufacturing (DFM) principles to provide a structure to support casting selection decision based on part features and process demand. The proposed software was developed using HTML and JavaScript, providing better usability than the previous proposed selection method using spreadsheets.

The results showed a good relation to the other methods, also providing a quantitative classification (prioritization) of the results. In addition, this software supports the design of the manufacturing process by means of a checklist to adapt the part to the metal casting process presented to the designer.

\section{References}

AKARTE, M. M.; RAVI, B. Casting product-process-producer compatibility evaluation and improvement. International Journal of Production Research, v. 45, n. 21, p. 4917 4936, 2007. http://dx.doi.org/10.1080/00207540600887661.

AMERICAN FOUNDRY SOCIETY - AFS. Illinois, 2015. Available from: <http://www.afsinc.org/ metalcasterdirectory/index.cfm>. Access in: 21 Sep 2015.

ASHBY, M. F. Materials selection in mechanical design. 3rd ed. Oxford: Butterworth-Heinemann, 2005.

ASSOCIAÇÃO BRASILEIRA DE FUNDIÇÃO - ABIFA. Índices de mercado ABIFA. São Paulo, 2012. Available from: $<$ http://www.abifa.org.br/Imagens/fle/IndicesMercado/
Desempenho/2012/DESEMPENHOMARCO2012.pdf>. Access in: 23 July 2014.

BOOThRoYD, G.; DEWHURST, P.; KNIGHT, W. A. Product design for manufacture and assembly. New York: CRC Press, 2011.

BRALLA, J. G. Design for manufacturability handbook. New York: McGraw-Hill, 1998.

CHANG, D.; CHEN, C.-H. Understanding the influence of customers on product innovation. International Journal of Agile Systems and Management, v. 7, n. 3-4, p. 348364, 2014.

COCHRAN, D. S. et al. Incorporating design improvement with effective evaluation using the Manufacturing System Design Decomposition (MSDD). Journal of Industrial Information Integration, v. 2, p. 65-74, 2016. http://dx.doi. org/10.1016/j.jii.2016.04.005.

DARWISH, S. M.; TAMIMI, A. A.; AL-HABDAN, S. A knowledge base for metal welding process selection. International Journal of Machine Tools \& Manufacture, v. 37, n. 7, p. 1007-1023, 1997. http://dx.doi.org/10.1016/ S0890-6955(96)00073-9.

DYNACAST. Die casting design. California, 2014. Available from: <http://www.dynacast.com/die-casting/diecastingdesign/fillet-radii $>$. Access in: 20 Apr 2014.

ELGH, F. Automated engineer-to-order systems: a taskoriented approach to enable traceability of design rationale. International Journal of Agile Systems and Management, v. 7, n. 3-4, p. 324-347, 2014.

ER, A.; DIAS, R. A rule-based expert system approach to process selection for cast components. Knowledge-Based Systems, v. 13, n. 4, p. 225-234, 2000. http://dx.doi. org/10.1016/S0950-7051(00)00075-7.

FERREIRA, J. M. C. Tecnologia da fundição. Lisboa: Fundação Calouste Glubenkian, 1999.

JONES, S.; YUAN, C. Advances in shell moulding for investment casting. Journal of Materials Processing Technology, v. 135, n. 2-3, p. 258-265, 2003. http://dx.doi. org/10.1016/S0924-0136(02)00907-X.

KARTHIK, S. et al. Methodology for metalcasting process selection. Pennsylvania: SAE International, 2003. SAE Technical Paper 2003-01-0431. http://dx.doi. org/10.4271/2003-01-0431.

KNIGHT, B.; COWELL, D.; PREDDY, K. An objectoriented support tool for the design of casting procedures. Engineering Applications of Artificial Intelligence, v. 8, n. 5, p. 561-567, 1995. http://dx.doi.org/10.1016/09521976(95)00037-2.

KUMAR, V.; MADAN, J.; GUPTA, P. A system for design of multicavity die casting dies from part product model. 
International Journal of Advanced Manufacturing Technology, v. 67, p. 1-25, 2013.

LOVATT, A. M.; SHERCLIFF, H. R. Manufacturing process selection in engineering design. Part 1: the role of process selection. Materials \& Design, v. 19, n. 5-6, p. 205-215, 1998a. http://dx.doi.org/10.1016/S0261-3069(98)00038-7.

LOVATT, A. M.; SHERCLIFF, H. R. Manufacturing process selection in engineering design. Part 2: a methodology for creating task-based process selection procedures. Materials \& Design, v. 19, n. 5-6, p. 217-230, 1998b. http://dx.doi. org/10.1016/S0261-3069(98)00039-9.

MEEHANITE. Casting design as influenced by foundry practice. Grafton, 2007. Available from: <http://www. meehanitemetal.com/designinfluence.pdf $>$. Access in: 21 Aug 2014.

NICHOLDS, B. A.; MO, J. P. T.; BRIDGER, S. Determining an action plan for manufacturing system improvement: a case study. International Journal of Agile Systems and Management, v. 7, n. 1, p. 1-25, 2014. http://dx.doi. org/10.1504/IJASM.2014.059145.

PULLAN, T. T. Decision support tool using concurrent engineering framework for agile manufacturing. International Journal of Agile Systems and Management, v. 7, n. 2, p. 132-154, 2014.
SANTOS, A. E. et al. Proposal and evaluation of a selection procedure for cast parts. Journal of the Brazilian Society of Mechanical Sciences and Engineering, v. 39, n. 8, p. 31513163, 2017. http://dx.doi.org/10.1007/s40430-017-0755-3.

SETTI, D. Método multicriterial para seleção de processos de fundição de metais. 2010. 184 f. Tese (Doutorado em Engenharia)-Programa de Pós-graduação em Engenharia de Produção, Universidade Federal do Rio Grande do Sul, Porto Alegre, 2010.

SUN, J. et al. Virtualisation and automation of curved shell plates' manufacturing plan design process for knowledge elicitation. International Journal of Agile Systems and Management, v. 7, n. 3-4, p. 282-303, 2014.

SWIFT, K. G.; BOOKER, J. D. Process selection: from design to manufacture. 2nd ed. Oxford: Butterworth-Heinemann, 2003.

VOSNIAKOS, G.-C. et al. The scope of artificial neural network metamodels for precision casting process planning. Robotics and Computer-integrated Manufacturing, v. 25, n. 6, p. 909-916, 2009. http://dx.doi.org/10.1016/j. rcim.2009.04.018.

WANG, Q. et al. The research and development of integrating database in casting process. Advanced Science Letters, v. 4, n. 8-9, p. 2946-2950, 2011. http://dx.doi.org/10.1166/ asl.2011.1532. 
Appendix 1. Checklist for casting processes.

\begin{tabular}{|c|c|c|}
\hline Process & $\begin{array}{c}\text { Verification } \\
\end{array}$ & Ok? \\
\hline \multirow{4}{*}{ Casting (general) } & Are abrupt approach/departure angles and small radius joints avoided? & \\
\hline & Are the section thicknesses as uniform as possible? & \\
\hline & Are the changes in section thickness as soft as possible? & \\
\hline & References: Associação Brasileira de Fundição (2012); Bralla (1998); Meehanite (2007). & \\
\hline \multirow{11}{*}{ Green sand and shell molding } & Do the section changes follow the literature recommendations? & \\
\hline & Do the T-joints have a member with the lowest possible thickness? & \\
\hline & Do the L- joints follow the literature recommendations? & \\
\hline & Do the V-joints follow the literature recommendations? & \\
\hline & Do the shoulders follow the literature recommendations? & \\
\hline & Have all possible X-shaped sections been eliminated? & \\
\hline & Were the gates correctly sized? & \\
\hline & $\begin{array}{l}\text { Are the holes larger than } 6 \mathrm{~mm} \text { in diameter for green sand or larger than } 3 \mathrm{~mm} \text { for shell } \\
\text { molding? }\end{array}$ & \\
\hline & Is the machining allowance between $1.5 \mathrm{~mm}$ and $6 \mathrm{~mm} ?$ & \\
\hline & Is the parting line a continuous line around the part? & \\
\hline & References: Swift and Booker (2003); Bralla (1998). & \\
\hline \multirow{5}{*}{ Precision casting } & Is the fillet minimum radius greater than $0.75 \mathrm{~mm}$ ? (Preferably between $1.5 \mathrm{~mm}$ and $3.0 \mathrm{~mm}$ ) & \\
\hline & Do the holes have diameters larger than $1.5 \mathrm{~mm}$ for ferrous and $2.2 \mathrm{~mm}$ for non-ferrous? & \\
\hline & Is the ratio between depth and diameter $4: 1$ for ferrous and $5: 1$ for non-ferrous? & \\
\hline & Inserts are not possible. Do projects not need them? & \\
\hline & References: Swift and Booker (2003); Bralla (1998). & \\
\hline \multirow{5}{*}{ Plaster mold casting } & Are the dimensions suited to process requirements? & \\
\hline & Is the machining allowance around $0.8 \mathrm{~mm}$ ? & \\
\hline & Are holes larger than $13 \mathrm{~mm}$ avoided? & \\
\hline & Is the material not magnesium? & \\
\hline & References: Swift and Booker (2003); Bralla (1998). & \\
\hline \multirow{8}{*}{ Permanent mold gravity casting } & Are the holes in the direction of separation of the mold? & \\
\hline & Are the dimensions of the internal radius larger than the mean thickness of the section? & \\
\hline & Are the dimensions of the external radius larger than 3 times the mean thickness of the section? & \\
\hline & Is the variation in the transverse section gradual? & \\
\hline & Is the allowance for machining between $0.8 \mathrm{~mm}$ and $2 \mathrm{~mm}$ ? & \\
\hline & Are the holes larger than $5 \mathrm{~mm}$ ? & \\
\hline & Are the critical dimensions not through the parting line? & \\
\hline & References: Swift and Booker (2003); Bralla (1998). & \\
\hline \multirow{8}{*}{ permanent mold under pressure casting } & Is the added material to be removed in machining between $0.25 \mathrm{~mm}$ and $0.5 \mathrm{~mm}$ ? & \\
\hline & Do the diameters of the holes respect the recommendations? & \\
\hline & Are the section changes as soft as possible? & \\
\hline & Do section changes respect the literature recommendations? & \\
\hline & Are the holes perpendicular to the parting line? & \\
\hline & Are the holes larger than $0.8 \mathrm{~mm}$ in diameter? & \\
\hline & Are the critical dimensions not through the parting line? & \\
\hline & References: Swift and Booker (2003); Bralla (1998); DYNACAST (2014). & \\
\hline
\end{tabular}

